\title{
PEMBUATAN KOMPOSIT POLIPROPILENA-BENTONIT UNTUK PLASTIK BIODEGRADABLE
}

\section{(SYNTHESIS OF BENTONITE - POL YPROPYLENE COMPOSITE USED FOR BIODEGRADABLE PLASTIC)}

\author{
Deswita, Ari Handayani, dan Evi Yulianti \\ Pusat Teknologi Bahan Industri Nuklir, BATAN \\ Kawasan Puspitek, Serpong 15314, Tangerang Selatan \\ E-mail : deswita@batan.go.id
}

Received : 29 Juni 2013; revised : 20 Nopember 2013; accepted : 12 Februari 2014

\begin{abstract}
ABSTRAK
Pembuatan komposit polipropilena-bentonit sebagai plastik biodegradable telah dilakukan. Tujuan dari penelitian ini adalah untuk mempelajari sifat mekanis dan biodegradasi bahan komposit dari bahan dasar polipropilena dengan filler bentonit dan penambahan agent 3-aminopropyl triethoxysilane (3-APE) sebagai coupling. Karakterisasi sampel dilakukan dengan peralatan Strograph-R1 untuk uji mekanis, Scanning Electron Microscope/Energy Dispersive Spectrophotometry (SEM/EDS) untuk pengamatan struktur mikro dan uji biodegradasi dilakukan dengan cara pemendaman dalam tanah. Hasil pengujian menunjukkan bahwa kekuatan tarik bahan komposit polipropilena-bentonit tanpa penambahan coupling 3-APE turun seiring dengan penambahan filler bentonit. Penurunan kekuatan tarik ini disebabkan oleh filler bentonit terdistribusi tidak homogen dan cenderung teraglomerasi di dalam bahan. Penambahan coupling agent 3-APE menyebabkan filler bentonit terdistribusi lebih homogen di dalam bahan dan menghasilkan peningkatan kekuatan tarik pada komposit polipropilena-bentonit. Uji biodegradasi di dalam tanah selama 3 minggu menunjukkan bahwa komposit polipropilena-bentonit mengalami perubahan warna dan pengurangan nilai kekuatan tarik.
\end{abstract}

Kata kunci : Polipropilena, Bentonit, Coupling, Plastik biodegradable

\begin{abstract}
The synthesis of bentonite-polypropylene composite biodegradable plastic materials has been done. The purpose of this research is to study the mechanical and biodegradation properties of a composite with a polypropylene base material and bentonite filler, and addition of 3-aminopropyl triethoxysilane (3-APE) as a coupling agent. Characterization of the samples was done by Strograph-R1 for mechanical testing, Scanning Electron Microscope/Energy Dispersive Spectrophotometry (SEM/EDS) for the observation of the microstructure and biodegradation test by buried in soil. The results showed that the tensile strength of bentonite-polypropylene composite without the addition of 3-APE coupling decrease with the addition of bentonite filler. Decrease in tensile strength is caused by the bentonite filler was not distributed homogeneously and tend to be agglomerated in the material. With the addition of 3-APE coupling agent, the bentonite filler was distributed more homogeneously in the materials and produce increasing a tensile strength of polypropylene-bentonite composite. Test biodegradation in the soil for 3 weeks showed that the polypropylene-bentonite composite become discolored and the tensile strength was decreased.
\end{abstract}

Keywords : Polypropylene, Bentonite, Coupling, Biodegradable plastic

\section{PENDAHULUAN}

Plastik telah banyak digunakan dalam berbagai jenis produk untuk memenuhi keperluan hidup manusia, mulai dari kantong plastik sampai komponen berteknologi tinggi. Bahan plastik banyak digunakan karena mempunyai keunggulan dari sifatnya yang ringan, transparan, tahan air, serta harganya pun relatif murah sehingga terjangkau oleh semua kalangan masyarakat. Disamping sifat unggulnya, plastik masih mempunyai sifat-sifat yang kurang menguntungkan yaitu tidak mudah hancur karena lingkungan, baik oleh cuaca 
hujan (air) dan panas matahari (suhu) ataupun mikroba yang hidup dalam tanah. Kalaupun dapat diuraikan, waktu yang diperlukan sangat lama (Gunawan 2008; Deswita 2010).

Pertumbuhan penggunaan plastik di negara maju mencapai 4\%, di Indonesia harusnya lebih tinggi lagi karena kebutuhan masih sekitar $10 \mathrm{~kg} /$ orang per tahun sementara di negara maju mencapai $50 \mathrm{~kg} /$ hari per tahun. Seiring dengan peningkatan penggunaan bahan plastik yang semakin pesat, maka banyak plastik yang diproduksi, berarti banyak juga plastik yang dibuang/terbuang. Hal ini menyebabkan banyaknya timbunan limbah plastik. Membakar limbah plastik mungkin menjadi pilihan selama ini, tetapi hal ini bisa membahayakan. Bahan kimia berbahaya seperti asam klorida dan hidrogen sianida dihasilkan dalam pembakaran plastik (Kartini et al. 2002). Selain dibakar, pilihan lain adalah dengan mendaur ulang plastik. Namun, hal ini juga memiliki banyak kendala seperti dalam pengumpulan dari berbagai macam jenis plastik yang berbeda dan juga tidak semua plastik dapat didaur ulang serta biaya pengolahan limbah begitu tinggi sehingga akan mempengaruhi biaya produksi. Oleh sebab itu, sekarang digunakan bahan alternatif lain untuk membuat material polimer yang ramah lingkungan (biodegradable). Polimer (plastik) biodegradable yang digunakan berasal dari monomer yang biodegradable, seperti polylactic acid (PLA), polyhydroxyalkanates (PHAs), dan trigliserida. Namun, polimer (plastik) biodegradable ini biaya produksinya sangat mahal (Averous 2012).

Mengingat hal tersebut diatas, maka dilakukan penelitian pembuatan komposit polimer sebagai bahan baku untuk industri plastik. Komposit polimer merupakan perpaduan antara dua atau lebih bahan yang mempunyai jenis dan sifat yang berbeda, serta sifat akhir komposit yang berbeda dengan sifat komponen penyusunnya. Komposit yang tersusun dari bahan polimer sebagai matriks dan bahan organik/anorganik sebagai pengisi (filler) yang dicampurkan ke dalam matriks, akan menghasilkan komposit dengan sifat akhir yang sangat tergantung pada karakteristik polimer serta distribusi bahan pengisi dalam matriks (Leong et al. 2003). Penambahan filler akan berdampak pada peningkatan sifat kekerasan, kemudahan proses, dan lebih mudah terdegradasi (Muller 2005; Nasrullah 2002; Othman et al. 2004). Filler yang digunakan adalah bentonit berukuran diameter rata-rata 0,34 $\mu \mathrm{m}$ yang memiliki sifat inert, berbentuk serbuk yang sangat halus, dan banyak terdapat di alam.
Namun demikian untuk mendapatkan kekuatan tarik bahan komposit yang optimum, filler yang digunakan harus terdistribusi secara homogen di dalam matriks, karena kekuatan tarik ditentukan oleh karakterisitik dan interaksi filler. Adhesi antar muka dan kekuatan tarik komposit dapat dinaikkan dengan menambahkan suatu zat yang berfungsi sebagai penggandeng (coupling agent) filler dengan matriks.

Bahan 3-aminopropyl triethoxysilane (3-APE) merupakan salah satu coupling agent silane yang berbahan dasar silikon. Bentonit sebagai filler juga mengandung silika (Si), diharapkan dapat terbentuk ikatan antara filler dengan matriks polipropilena. Variasi jumlah volume coupling agent yang ditambahkan dimaksudkan agar diperoleh jumlah volume yang tepat untuk ditambahkan dalam komposit dengan hasil kuat tarik yang maksimal.

Pada penelitian ini dibuat dua bahan komposit yaitu polipropilena-bentonit dan polipropilena-bentonit-coupling agent 3-APE. Polipropilena yang digunakan adalah tipe melt flow (MF) 35 dan 10 sebagai matriks, bentonit sebagai filler, dan 3-APE sebagai coupling agent. Bahan komposit yang diperoleh berbentuk pelat film yang kemudian dikarakterisasi meliputi uji kuat tarik (tensile strength), kuat luluh (yield strength), dan perpanjangan putus (elongation break) dengan alat strograph-R1, uji kekerasan dengan alat shore A, peralatan Scanning Electron Microscope (SEM) untuk mengamati struktur mikro dan uji degradasi.

\section{BAHAN DAN METODE}

\section{Bahan}

Bahan yang digunakan dalam penelitian adalah polipropilena (PP) tipe melt flow (MF) 10 dan 35 atau dikenal sebagai PP10 dan PP35, diperoleh dari PT. Tri Polyta Cilegon, Banten. Bentonit (katalog Aldrich), 3-APE, $\mathrm{H}_{2} \mathrm{~N}\left(\mathrm{CH}_{2}\right)_{3} \mathrm{Si}\left(\mathrm{OC}_{2} \mathrm{H}_{5}\right)_{3}$ atau 3-APE dengan kemurnian 99\% (katalog Aldrich).

\section{Metode}

Pembuatan komposit polipropilenabentonit dilakukan dengan cara memasukkan polipropilena ke dalam sebuah labo plastomill (model 30R150), diaduk beberapa saat, kemudian dimasukkan bentonit secara bertaHAp. Proses pencampuran (blending) dilakukan pada suhu $180{ }^{\circ} \mathrm{C}$ dengan kecepatan putar 40 rpm selama 10 menit. Variasi komposisi perbandingan (dalam persen berat) antara PP (tipe MF 35 dan MF 10) dengan bentonit 
dilakukan berturut-turut adalah 70:30; 60:40; 50:50; 40:60; dan 30:70.

Pembuatan bahan komposit polipropilenabentonit-3APE dilakukan dengan cara mencampur bentonit dengan 3-APE yang telah diencerkan dalam etanol. Setiap $20 \mathrm{~g}$ bentonit, dicampurkan 3-APE dengan variasi penambahan $10 \mathrm{ml}, 20 \mathrm{ml}, 30 \mathrm{ml}$, dan $40 \mathrm{ml}$ dan dikeringkan di dalam oven. Kemudian polipropilena (MF 35 dan MF 10) dicampur dengan bentonit yang telah dicampur dengan coupling agent 3-APE, untuk perbandingan komposisi masing-masing PP35 dan PP10 dengan bentonit 50:50. Polipropilena dimasukkan ke dalam labo plastomill, diaduk beberapa saat kemudian dimasukkan bentonit secara bertaHAp. Proses pencampuran dibiarkan selama beberapa saat.

Bahan komposit PP35 dan PP10-bentonit dan komposit PP35 dan PP10-bentonit- 3-APE hasil dari pencampuran, selanjutnya dibuat dalam bentuk plat film. Alat cetak film dimasukkan ke dalam mesin pengepres panas kemudian dimasukkan ke dalam mesin pengepres dingin. Film yang dihasilkan kemudian diuji menggunakan peralatan Strograph-R1 untuk mengetahui sifat mekanis meliputi kuat tarik, perpanjangan putus, digunakan Scanning Electron Microscope (SEM) untuk mengamati struktur mikro sampel dan Alat Shore A Zwick ISO/R 868 digunakan untuk mengetahui kekerasan sampel.

$\mathrm{TaHAp}$ pengujian biodegradable dilakukan dengan uji dalam tanah dan uji dalam ruangan (sebagai perbandingan). Setiap 3 minggu sekali sampel diambil untuk ditimbang berat dan diuji sifat mekanisnya.

\section{HASIL DAN PEMBAHASAN}

Hasil uji kekuatan tarik bahan komposit (PP10 dan PP35)-bentonit ditunjukkan pada Gambar 1. Kurva Gambar 1. menunjukkan bahwa kekuatan tarik bahan dasar PP10 dan PP35 sebelum dibentuk bahan komposit masing-masing diperoleh sekitar $364 \mathrm{~kg} / \mathrm{cm}^{2}$ dan $300 \mathrm{~kg} / \mathrm{cm}^{2}$. Namun setelah dibentuk bahan komposit dengan kandungan filler bentonit bervariasi dari $30 \%$ sampai $70 \%$, kekuatan tarik dari kedua bahan tersebut cenderung mengalami penurunan seiring dengan bertambahnya komposisi filler bentonit, baik untuk dari bahan PP10 maupun bahan PP35.

Berdasarkan kurva Gambar 1, kekuatan tarik komposit polipropilena-bentonit untuk polipropilena, PP10 lebih tinggi dibandingkan dengan kuat tarik komposit polipropilena PP35.
Hal ini disebabkan karena polipropilena PP10 memiliki derajat kristalinitas yang lebih tinggi dibandingkan dengan polipropilena PP35. Semakin besar derajat kristalinitas maka keteraturan atom-atom pada struktur molekul semakin tinggi, sehingga kompatibilitas semakin besar dan menyebabkan kekuatan tarik PP10 tinggi. Selain itu, terbentuknya adhesi antar muka (interface) antara polipropilena dengan bentonit lemah yang disebabkan karena bentonit sebagai filler merupakan lempung hidrofilik dengan layer silikat termasuk hidroksi polar sedangkan polimer polipropilena merupakan matriks hidrofob material non polar, jadi keduanya sangat sulit terdispersi secara homogen (Sarkar 2008). Hal ini telah diamati pada penelitian terdahulu, yaitu pembuatan bahan komposit polipropilena menggunakan filler talk, $\mathrm{CaCO}_{3}$, kaolin, dan serbuk kayu gergaji (Stevens 2001; Syuada 2008), sehingga jelas bahwa banyaknya penambahan filler bentonit membuat komposit PP-bentonit cenderung menjadi bersifat getas, mudah patah (Wisojodharmo 2003).

Adhesi antar muka dan kekuatan tarik komposit dapat dinaikkan dengan menambahkan suatu zat yang berfungsi sebagai penggandeng (coupling agent) filler dengan matriks. Pada penelitian ini, digunakan 3-APE yang merupakan coupling agent silane yang berbahan dasar silikon. Variasi jumlah volume yang tepat untuk mendapatkan bahan komposit dengan hasil kuat tarik yang maksimal, seperti ditunjukkan pada Gambar 2.

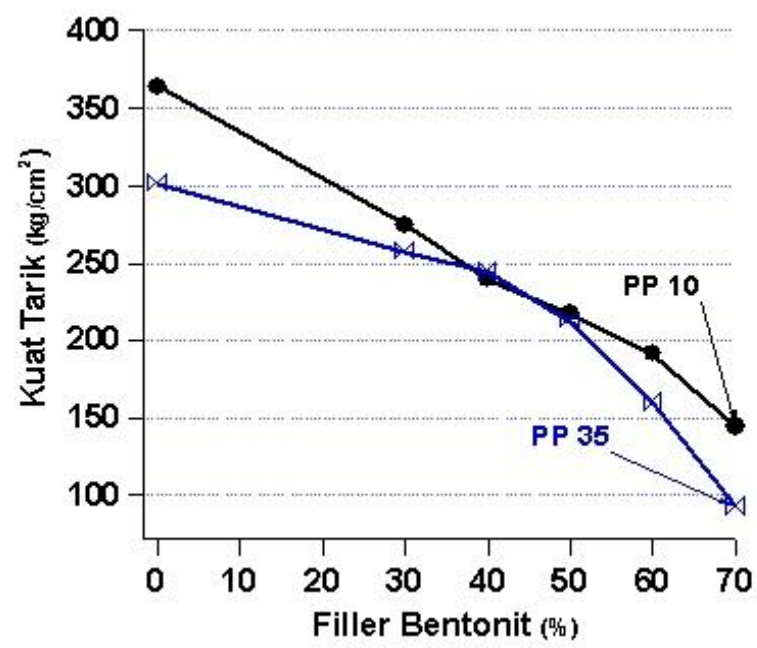

Gambar 1. Kurva hubungan antara kuat tarik terhadap persentase komposisi filler bentonit 


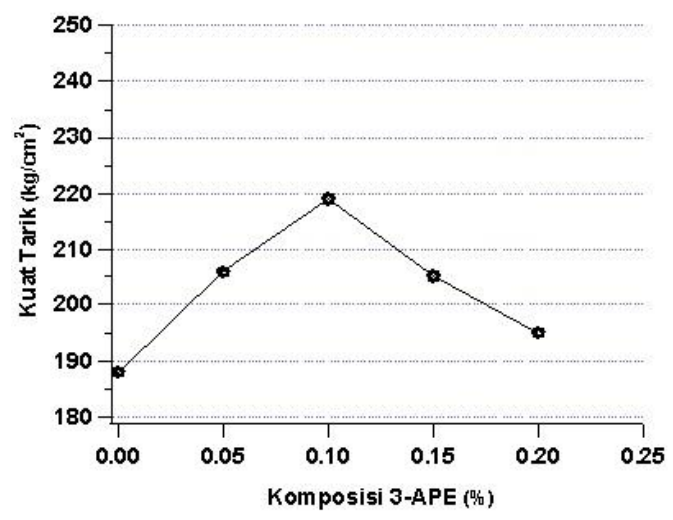

Gambar 2. Kurva hubungan antara kekuatan tarik komposit PP35-bentonit terhadap kandungan coupling agent 3-APE. Perbandingan PP35 : bentonit adalah $50 \%: 50 \%$.

Berdasarkan kurva Gambar 2. menunjukkan bahwa kekuatan tarik bahan komposit PP35-bentonit cenderung meningkat dengan menggunakan coupling agent $3-A P E$ hingga komposisi 0,1 ; namun kemudian turun seiring dengan penambahan coupling agent $3-A P E$ yang lebih besar. Hal ini sangat mungkin menunjukkan adanya ikatan antar muka coupling agent dengan filler dan matriks yang baik, sehingga menyebabkan kekuatan tarik meningkat. Kekuatan tarik yang tertinggi diperoleh sekitar $219 \mathrm{~kg} / \mathrm{cm}^{2}$, untuk perbandingan kandungan PP35 : bentonit adalah $50 \%$ : $50 \%$ dengan volume kandungan coupling agent $3-A P E$ sekitar $0,1 \%$.

Gambar 3a. menunjukkan kurva hubungan antara komposisi filler bentonit terhadap kekerasan dari masing-masing polipropilena yang digunakan. Pada Gambar kurva 3a. terlihat bahwa kedua bahan komposit PP10-bentonit dan PP35-bentonit, kekerasan meningkat seiring dengan penambahan filler. Banyaknya filler bentonit membuat kepadatan dalam komposit meningkat, sehingga meningkatkan kekerasan bahan.

Pada komposit PP35(50)\%-bentonit(50\%)$3-A P E(0,05 \%)$, kekerasan bahan komposit mengalami sedikit penurunan. Namun kemudian, kekerasan bahan komposit cenderung naik kembali dengan penambahan $3-A P E$ hingga 0,2\% (lihat Gambar 3b).

Berdasarkan Gambar 3, kekerasan (hardness) bahan komposit PP35-bentonit yang optimum, dengan komposisi $50 \%$ : $50 \%$, setelah dicampur dengan $3-A P E$ sebesar $0,1 \%$ diperoleh sekitar 93 (shore) sedikit lebih rendah bila dibandingkan dengan kekerasan bahan komposit PP35-bentonit tanpa 3-APE sebesar 94 (shore) (lihat Gambar 3a).

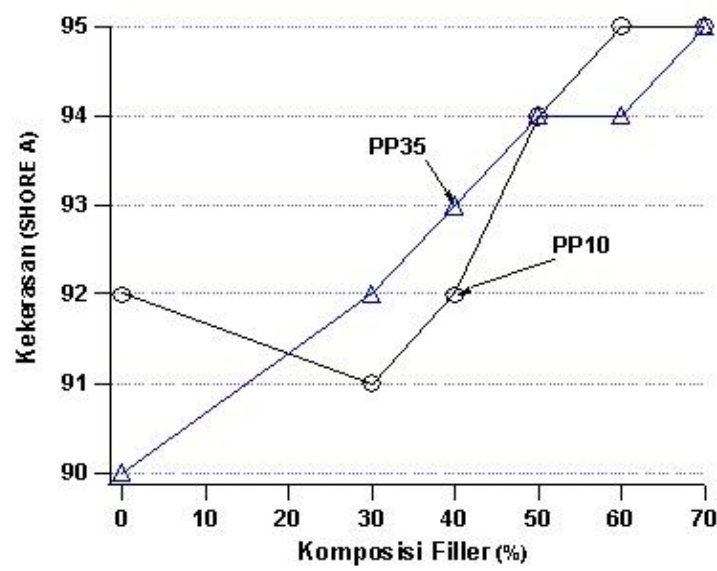

(a)

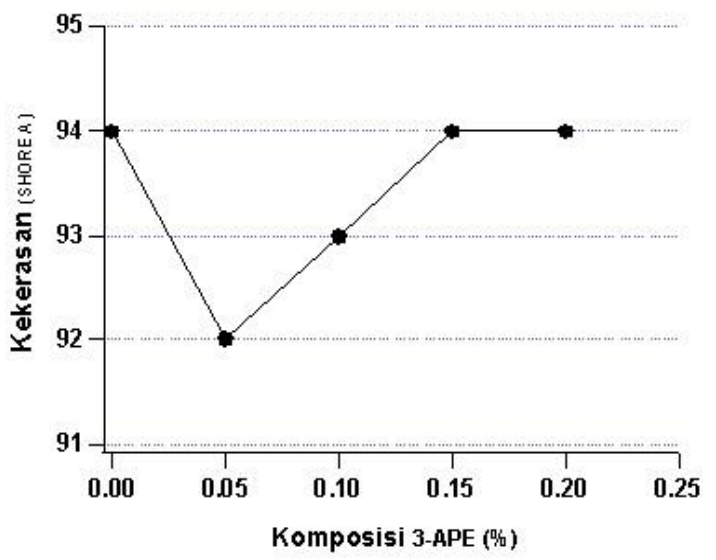

(b)

Gambar 3. Grafik pengaruh komposisi filler bentonit terhadap kekerasan bahan komposit a) PP10 dan 35-bentonit, b) PP35(50\%)bentonit(50\%)-3APE $(0,1 \%)$

\section{Morfologi Komposit Polipropilena-Bentonit}

Struktur mikro polipropilena MF 10 dan MF 35 atau disingkat PP10 dan PP35 hasil pengamatan dengan SEM ditunjukkan pada Gambar 4a dan Gambar 4b. Berdasarkan Gambar 4a dan Gambar4b, tampak bahwa morfologi PP10 dan PP35 yang berperan sebagai matriks memperlihatkan fase kontinyu yang tunggal. Penambahan filler bentonit ke bahan polipropilena dengan membentuk bahan komposit pilipropilena-bentonit, morfologi bahan dasar semula terlihat mengalami perubahan yang signifikan (lihat Gambar 4c sampai dengan Gambar 4e). Gambar 4c sampai dengan Gambar 4e memperlihatkan distribusi filler bentonit (warna putih) di dalam bahan komposit dengan matriks PP MF 10 dan PP MF 35 dengan ratio kandungan PP : bentonit adalah 50\%:50\% (Gambar 4c dan Gambar 4d), sedang Gambar $4 \mathrm{e}$ dengan pemakaian coupling 3-APE $0,1 \%$. 
Berdasarkan foto SEM dari Gambar 4c dan Gambar 4d, terlihat bahwa filler bentonit terdistribusi tidak homogen, membentuk fase diskontinyu dan cenderung mengalami aglomerasi di dalam bahan komposit PP10-bentonit (Gambar 4c) dan PP35-bentonit (Gambar 4d). Tampak pada Gambar 4c dan Gambar 4d, masih banyak filler bentonit berukuran antara $5 \mu \mathrm{m}$ sampai $10 \mu \mathrm{m}$ dan lebih besar bila dibandingkan dengan filler bentonit yang terdistribusi di dalam bahan komposit PP35-bentonit dengan coupling 3-APE yang berukuran lebih kecil dari $5 \mu \mathrm{m}$ (lihat Gambar 4e).

Dari hasil pengujian ini jelas bahwa besarnya ukuran partikel filler bentonit yang terdistribusi di dalam bahan komposit tersebut menyebabkan bahan menjadi keras, namun ikatan permukaan antara filler dengan matriks menjadi lemah sehingga akibatnya, kuat tarik bahan secara keseluruhan rendah, dan bahan menjadi keras dan getas.

Hasil pengamatan dengan SEM/EDS menunjukkan bahwa unsur silicon (Si) meningkat dari sekitar $3,9 \%$ menjadi sekitar $6,5 \%$ di dalam komposit. Demikian pula unsur oksigen (O) juga meningkat dari $26 \%$ menjadi $45 \%$. Sebaliknya, unsur karbon (C) berkurang cukup signifikan dari sekitar $68 \%$ menjadi sekitar $45 \%$ setelah ditambahkan $3-A P E$. Unsurunsur lain seperti $\mathrm{Na}, \mathrm{Al}, \mathrm{Na}, \mathrm{P}, \mathrm{Cl}$, dan Fe tidak mengalami perubahan yang signifikan.

Pengujian biodegradable dilakukan dengan cara disimpan di dalam ruangan (kontrol) selama 6 minggu dan ditimbun dalam tanah selama 3 minggu dan 6 minggu. Pada rentang waktu dari 3 minggu sampai 6 minggu, secara visual sampel sudah mengalami degradasi warna menjadi memudar seperti pada Gambar 5b dan Gambar 5c.

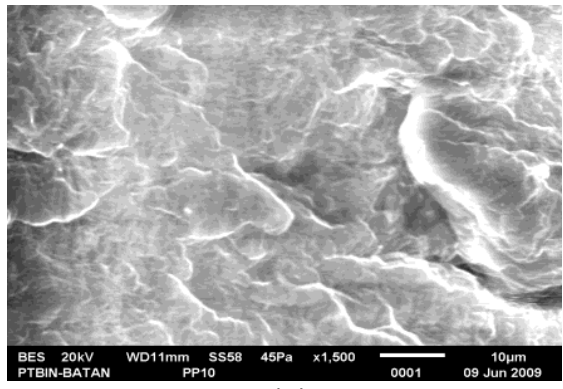

(a)

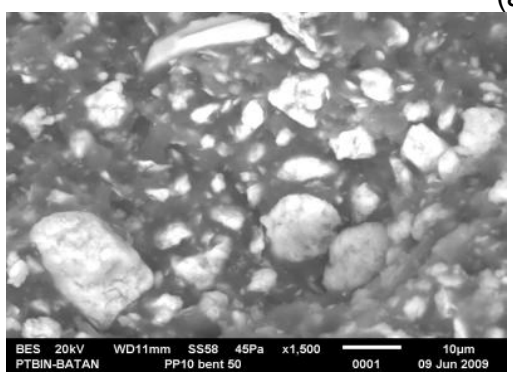

(c)

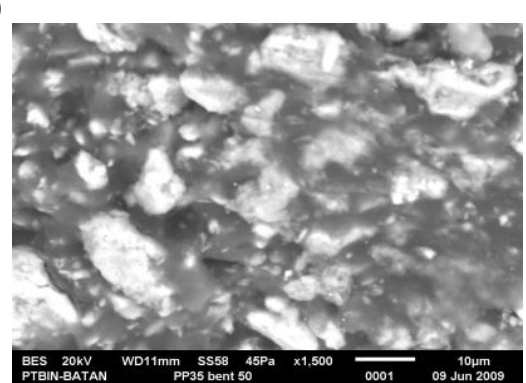

(d)

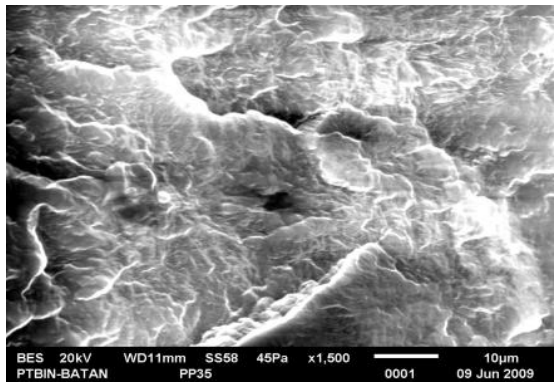

(b)

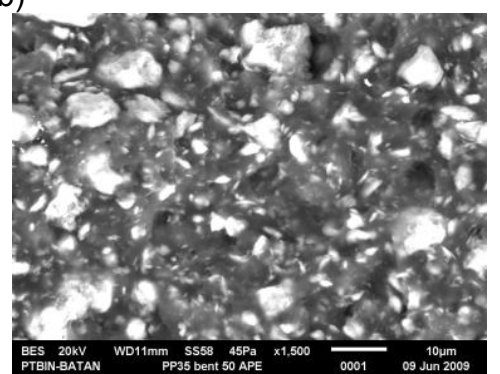

(e)

Gambar 4. Morfologi SEM a) PP10, b) PP 35, komposit c) PP10-bentonit, d) PP35-bentonit, dan e) PP35(50\%)-bentonit(50\%)-3 APE 0,1\%

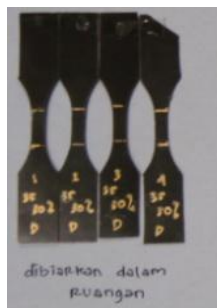

(5a)

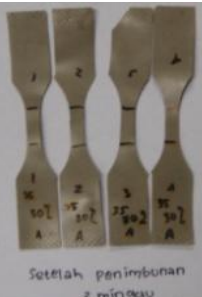

(5b)

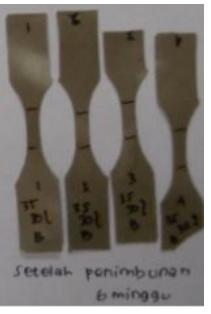

$(5 c)$

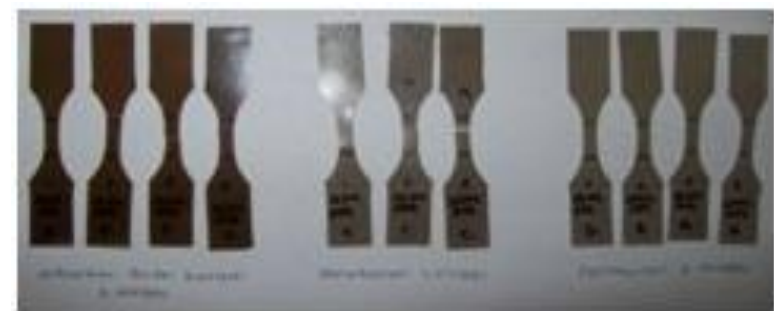

$(5 d)$
$(5 e)$

(5f)

Gambar 5. Uji biodegradable terhadap bahan komposit PP-bentonit setelah dilakukan penimbunan a) control, b) 3 minggu, c) 6 minggu dan komposit PP35(50\%)-bentonit(50\%)-3 APE(0,1\%) setelah dilakukan penimbunan d) control, e) 3 minggu, f) 6 minggu 
Degradasi berat seharusnya menyebabkan berat sampel berkurang, akan tetapi dalam hal ini justru menyebabkan sampel bertambah lebih berat. Hal ini disebabkan karena filler bentonit yang digunakan merupakan bahan absorben yang dapat mengikat air. Namun demikian, proses degradasi akan berdampak terhadap perubahan kekuatan tarik, seperti ditunjukkan pada Gambar 6 .

Kurva perubahan sifat mekanis bahan komposit PP10-bentonit, PP35-bentonit, dan PP35-bentonit dengan coupling 3-APE ditunjukkan pada Gambar 6. Berdasarkan kurva kuat tarik pada Gambar 6 menunjukkan bahwa kekuatan tarik bahan komposit baik PP10-bentonit maupun PP35-bentonit mengalami penurunan, setelah ditimbun selama 3 minggu sampai 6 minggu (lihat Gambar 6a dan Gambar 6b). Hal ini menunjukkan bahwa semakin lama waktu penimbunan, maka bahan akan semakin terdegradasi. Namun pada sampel kontrol yang didiamkan dalam ruangan, sampel tidak mengalami perubahan warna atau warna tetap sama. Demikian pula untuk komposit PP35-bentonit yang menggunakan 3-APE seperti pada Gambar 6c, kuat tarik bahan komposit berkurang seiring dengan bertambahnya komposisi kandungan coupling, setelah ditimbun selama 3 minggu sampai 6 minggu.

Berdasarkan kurva hasil uji kuat tarik tersebut di atas, jelas bahwa penimbunan di dalam tanah selama 3 minggu dan 6 minggu menyebabkan bahan komposit PP10 dan PP35 dengan filler bentonit telah mengalami proses degradasi, terutama pada komposit PP35 dengan filler bentonit yang menggunakan coupling 3-APE. Hal ini karena plastik dan komposit sensitif terhadap perubahan lingkungan, kekuatan tarik (tensile strength) berubah-ubah sesuai dengan kondisi lingkungannya, oleh uap air atau kelembaban.

Dari kurva hasil uji kekerasan Gambar 7a dan Gambar 7b, terlihat bahwa komposit PP10 dan PP35 dengan filler bentonit mengalami penurunan cukup tajam terhadap sampel awal, setelah ditimbun di dalam tanah selama 3 minggu sampai 6 minggu. Namun untuk komposit PP35-bentonit yang menggunakan coupling 3-APE, kekerasan bertambah untuk komposisi coupling rendah yaitu $0,05 \%$. Setelah 3 minggu ditimbun, kekerasannya sedikit mengalami penurunan untuk kandungan coupling $3-A P E$ sebesar $0,1 \%$ dan setelah ditimbun selama 6 minggu untuk kandungan coupling $3-A P E \quad 0,15 \%$ dan $0,20 \%$ kekerasan mengalami penurunan terhadap sampel awal (lihat Gambar 7c).

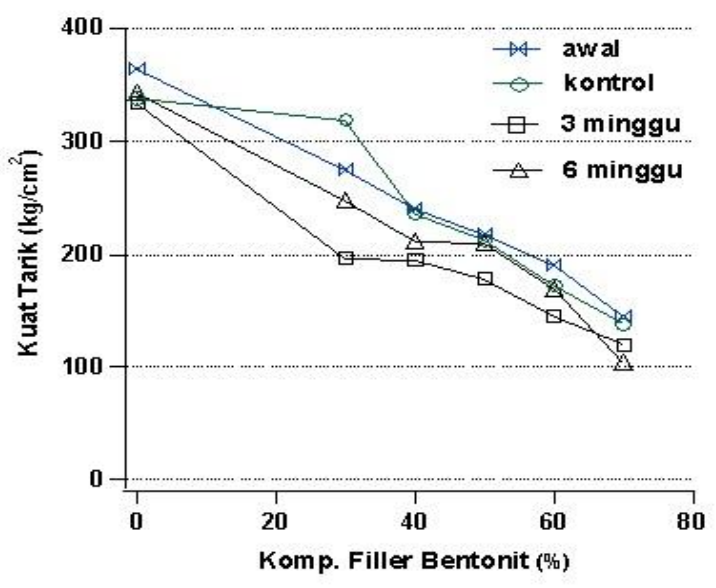

(6a)

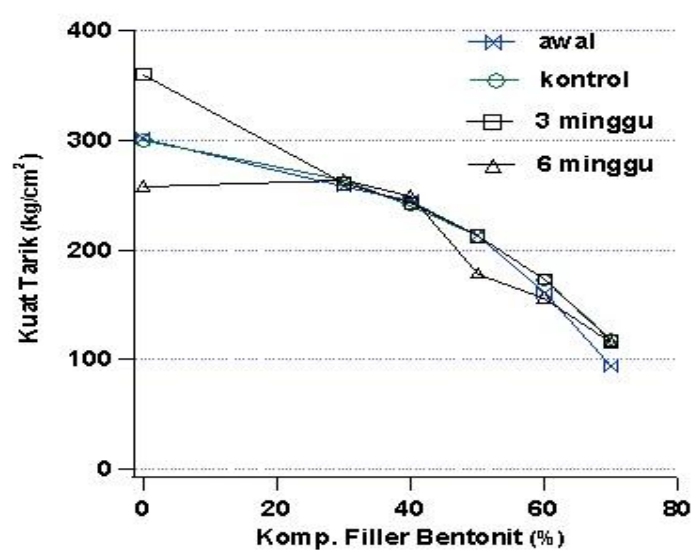

(6b)

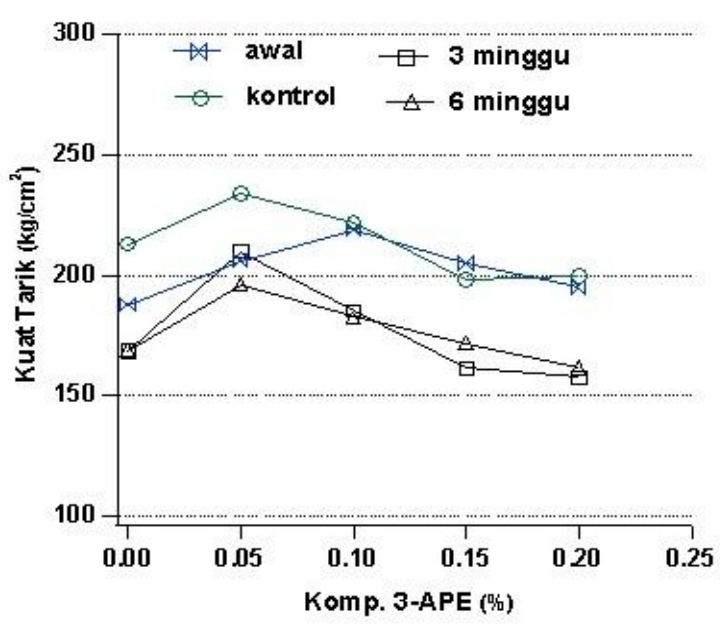

(6c)

Gambar 6. Kurva pengaruh komposisi filler bentonit vs kuat tarik a) komposit PP10-bentonit, b) komposit PP35-bentonit, dan c) pengaruh komposisi coupling $3-A P E$ vs kuat tarik komposit PP35 (50\%) bentonit (50\%) - $3 A P E$ 
Namun seiring dengan bertambahnya filler bentonit dalam komposit, kekerasan semakin meningkat. Hal ini disebabkan oleh filler bentonit yang bersifat sebagai absorben sehingga dapat menyerap mineral dan air dari dalam tanah, yang bisa meningkatkan kekerasan bahan.

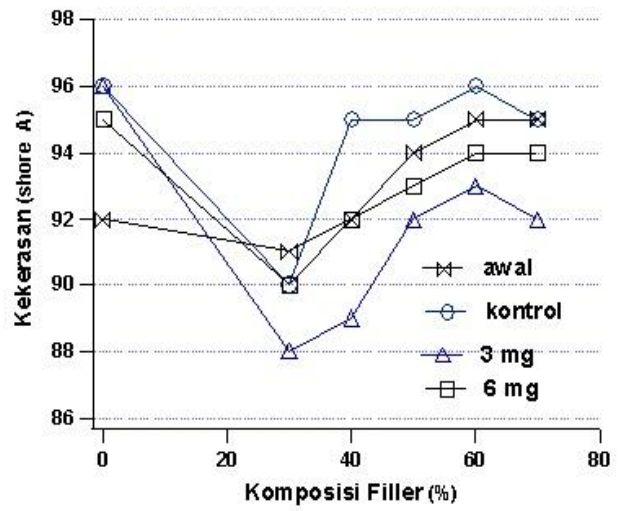

(7a)

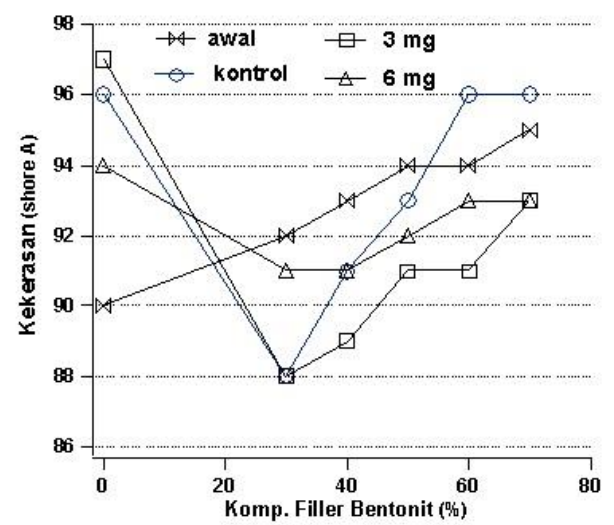

(7b)

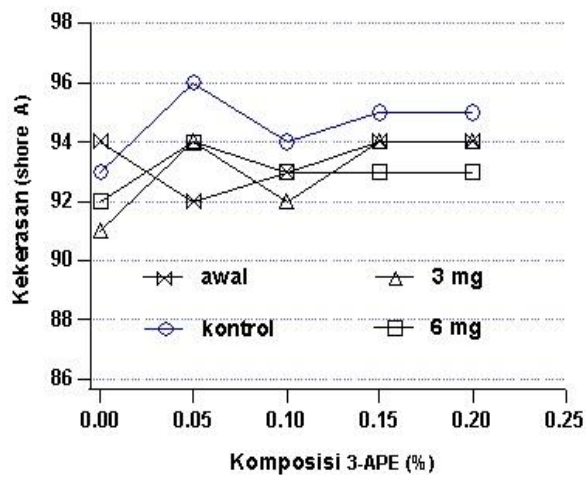

(7c)

Gambar 7. Kurva pengaruh komposisi filler bentonit vs kekerasan a) komposit PP10-bentonit, b) komposit PP35-bentonit, dan c) pengaruh komposisi coupling 3-APE vs kekerasan komposit PP35 (50\%) bentonit (50\%) - 3 APE
Gambar kurva pada Gambar 7 terlihat naik turun kurang stabil, hal ini disebabkan oleh kekerasan yang tidak bisa diukur dengan tepat dan juga disebabkan distribusi ukuran dalam komposit yang kurang merata.

Dari hasil uji mekanis tersebut di atas menunjukkan bahwa komposit dari matriks polipropilena, PP10, dan PP35 dengan filler bentonit serta menggunakan coupling agent $3-A P E$ telah mengalami proses degradasi setelah ditimbun dalam tanah selama 3 minggu dan 6 minggu. Hal ini diperlihatkan oleh semakin menurunnya kuat tarik dan kekerasan bahan komposit polipropilena-bentonit dengan ataupun tanpa pemakaian coupling agent 3-APE. Namun Kekuatan tarik bahan pada sampel kontrol yang didiamkan dalam ruangan selama 3 minggu sampai 6 minggu hampir sama dengan kekuatan tarik awal.

\section{KESIMPULAN}

Berdasarkan uraian pembahasan yang telah dikemukakan dan hasil penelitian yang telah dilakukan, maka dapat diambil kesimpulan bahwa bahan komposit berbasis matriks polipropilena tipe melt flow 10 (PP10) dan melt flow 35 (PP35) dengan filler bentonit serta menggunakan coupling agent $3-A P E$ telah berhasil dibuat. Sifat mekanis komposit PP10 dan PP35 dengan filler bentonit cenderung turun dengan bertambahnya kandungan bentonit, namun kekerasan bahan komposit tersebut bertambah. Pengaruh penambahan filler bentonit dalam komposit dapat diketahui bahwa semakin banyak filler yang ditambahkan, maka sifat mekanisnya semakin menurun, kekerasan semakin meningkat dan bahan akan semakin mudah terdegradasi. Komposit dengan PP MF 10 mempunyai kekuatan tarik yang lebih tinggi daripada komposit dengan PP MF 35. Pengaruh penambahan coupling agent dalam komposit dapat meningkatkan kekuatan tarik dan mempercepat terjadinya degradasi. Kekuatan tarik maksimal diperoleh pada penambahan coupling agent komposisi $0,1 \% \mathrm{w} / \mathrm{w}$.

\section{DAFTAR PUSTAKA}

Gunawan, I., Deswita, A. Karo-Karo, dan Sudirman. 2008. Sintesis dan karakterisasi komposit high density polyethylene-pati tapioka. Jurnal Sains Materi, Desember : 5-8.

Deswita, A. Karo-Karo, G.T. Sulungbudi, dan Sudirman. 2010. Sintesis dan karaterisasi polipropilena dengan filler 
tepung tapioka untuk bahan kemasan. Jurnal Sains Materi Indonesia 12 (1) : 24-29.

Kartini, R., H. Darmasetiawan, A. Karo-Karo, dan Sudirman. 2002. Pembuatan dan karakterisasi komposit polimer berpenguat serat alam. Jurnal Sains Materi Indonesia 3 (3) : 30-38.

Averous, L. and E. Pollet. 2012. Environmental silicate nano-biocomposites. green energy and technology. SpringerVerlag London : 13-39.

Leong, W.Y., M.B. Abu Bakar, Z.A. Mohd Ishak, A. Arifin, and B. Pukanszky. 2003. Comparison of the mechanical properties and interfacial interaction between talc, kaolin, and calcium carbonate filled polypropylene composite. Journal of Applied Polymer Science 91:3315-3326.

Lever, A. F. 1971. The plastic manual. The Scientific press London.

Muller, R. J. 2005. Biodegradability of polymer : regulation and methods for testing. Gesellschaft fur Biotechnologische Forschung $\mathrm{mbH}$, Braunschweig, Germany. 365-374.

Nasrullah, F. 2002. Pemanfaatan limbah serbuk kayu gergaji sebagai filler pada komposit poliester. Fakultas Matematika dan IImu Pengetahuan
Alam, Universitas Syahkuala, Aceh. Indonesia.

Othman, N., H. Ismail, and M. Jaafar. 2004. Preliminary study on application of bentonite as a filler in polypropylene composites, Polymer-plastics technology and engineering, 43: 713-730.

Pasaribu, N. 2004. Berbagai ragam pemanfaatan polimer. Jurusan Kimia. Fakultas Matematika dan IImu Pengetahuan, Universitas Sumatera Utara, Medan. Indonesia.

Sarkar, M., K. Dana, S. Ghatak, and A. Banerjee. 2008. Polypropylene-clay composite prepared from indian bentonite. Bull. Mater. Sci 31: 23-28.

Stevens, M. 2001. Kimia polimer, diIndonesiakan oleh lis Sopyan dan Pradnya Paramita, Jakarta. Indonesia.

Syuhada, R. Wijaya, Jayatin, dan S. Rohman. 2009. Modifikasi bentonit (clay) menjadi organoclay dengan penambahan surfaktan. Jurnal Nanosains dan Nanoteknologi, 2(1) : 48-51.

Wisojodharmo, L. A. 2003. Pembuatan pengemas plastik ramah lingkungan (biodegradable) dari bahan campuran pati tapioka-polietilen. Prosiding Seminar Seknologi untuk negeri, 1:361-370. 